\title{
EVALUATING CURRENT TURKISH POLITICS IN LIGHT OF DEMOCRATIZATION AND EUROPEANIZATION THEORIES: THE CASE OF EDUCATION REFORMS
}

\author{
EREN ÖZALAY-ŞANLI* \\ Bahçeşehir University
}

\begin{abstract}
This article traces the achievements of democratization and Europeanization in Turkey through debates about reforming education. After a discussion on Europeanization and democratization theories and on how well these theories explain the reform process in Turkey, the article delves into the question of how education norms that were developed during the European integration have affected domestic policy in Turkey. Education is a policy area left to the discretion of national governments within the European Union; therefore supranational legislation governing education does not exist. Education is not a problematic issue in the Turkish accession negotiations. Nevertheless, the pressing need for reform is stated in the annual progress reports when the practice of education in Turkey contradicts the norms of human rights as well as cultural and democratic rights. Recent education reforms and debates about future developments in education suggest important trajectories for understanding the current state of Turkey-EU relations and how far the mechanisms offered by the EU and other European institutions have worked for the further democratization of Turkey. The fact that some norms are accepted while others are rejected proves the instrumental impact of Europeanization in Turkey. The article finds the norm diffusion model accords with the rational institutionalist model of Europeanization in explaining education reforms in Turkey.
\end{abstract}

Keywords: Europeanization, democratization, rational choice institutionalism, norm diffusion, education reform.

\section{TÜRK SIYYASETINİ DEMOKRATIKLESME VE AVRUPALILASMA TEORILLERI

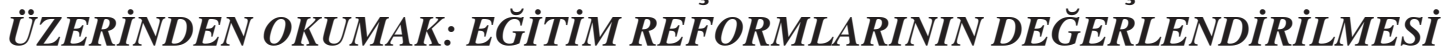

\section{ÖZET}

Bu makalede ĕgitimde yapılan reformlar üzerinden Türkiye'de Avrupalılaşma ve demokratikleşme süreçlerinin etkisi incelenmektedir. Avrupalılaşma ve demoktarikleşme teorileri tartışılarak bu iki teorinin Türkiye'de reform sürecini açıklamakta ne derece etkin olduğu ortaya konmakta, buna mukabil hangi teorik yaklaşımın Avrupa entegrasyon sürecinde gelişen eğitim normlarının Türkiye'deki etkisini daha iyi açıkladı̆̆ sorusu cevaplanmaktadır. Ĕ̆itim AB üye devletlerinin ulusal politika alanlarından biridir ve eğitim konusu uluslarüstü kanunlarla düzenlenmemektedir.

* Eren Özalay-Şanlı is a Ph.D. candidate in the Department of Political Science and International Relations at Boğaziçi University, Bebek, 34342, İstanbul, Turkey and a Research Assistant in the Department of EU Studies at Bahçeşehir University, Beşiktaş, 34353, İstanbul, Turkey. E-mail: eren.ozalay @ bahcesehir.edu.tr 
Türkiye’nin üyelik müzakerelerinde eğitim konusu problemli olmamakla birlikte, e ğitim politikası müzakere sürecinde insan haklarl, demokratik ve kültürel haklarla ilgili olarak sorun teşkil etmekte ve ilerleme raporlarında yer almaktadır. Böylelikle eğitim alanında Avrupalılaşma ve demokratikleşme süreçlerinde gerçekleştirilen reformlar Türkiye'nin Avrupa ile olan ilişkilerini ve demokratikleşme sürecinde Avrupa Birliği’nin sunduğu mekanizmaların işleyişini anlamakta önemli ipuçları sunmaktadır. Ĕ̈itim konusunda bazı normların kabul edilirken bazılarının reddi, Avrupalılaşmanın araçsal bir seviyede seyrettiğine kanıt oluştururken, makale eğitim reformlarını açılamakta norm difüzyonu modelinin, rasyonel tercih kurumsalcılığı perspektifini tamamladı̆̆ını iddia etmektedir.

Anahtar kelimeler: Avrupalılaşma, demokratikleşme, rasyonel tercih kurumsalcılı̆̆ı norm difüizyonu, ĕ̆itim reformu.

This paper traces the achievements of democratization and Europeanization in Turkey through debates about reforming education. Turkey is going through rapid democratization and Europeanization which this article argues have been interdependent processes since the late 1980s. The candidacy status of the country to the European Union which was announced at the 1999 Helsinki Summit added a certain momentum to these efforts. The harmonization packages approved by the Turkish Grand National Assembly from 2002 to 2004 are examples of the direct impact of these processes. After a decade since Turkey's candidacy status was announced, it is now time to assess the impact of these two processes on a domestic policy issue. This article tries to evaluate the reforms in the area of education with respect to democratization and Europeanization theories and to see how well these theories explain the recent reforms in Turkey.

Education is a policy area left to the discretion of national governments within the European Union, and therefore supranational legislation governing education does not exist as it does in other policy areas such as competition, economic and monetary policy and agriculture. However, there are norms about education that have been developed and practiced at the EU level. Education is not a problematic issue in the negotiation process for Turkey and there are no conditions imposed by the EU regarding education in order for the country to become a member of the European Union. Still, the facts that the content of education and the educational policy touch upon issues such as minority rights, human rights and religious freedoms make it a policy area that one can measure for the indirect impact of Europeanization on democratization reforms in Turkey.

Education policy and reform in Turkey could be studied under two major headings. The first is the technical improvement of education which includes increasing the percentage of schooling, providing access to technology to students and teachers, and improving the skills and competencies of teachers. The second major heading is the content of education which includes textbooks and curricula. This is where the policy of education is linked to issues of human rights, democracy and citizenship norms. This paper will touch upon the content of the social sciences and history classes. It is this connection between human rights and identities of minorities that makes the debates about the subjects of history, social sciences and religious education an issue of democratization and Europeanization for the Turkish case. Therefore in the initial sections of this paper, democratization and Europeanization theories will be introduced as two alternative explanations for assessing the domestic impact. The following section discusses how these theories account for domestic change in the case of Turkey in general. After a brief summary of the current state of education in Europe and education norms developed at the EU 
level, the paper takes a closer look at the education policy in Turkey and at how this specific policy area has been transformed due to international influences in the last decade. In the conclusion the applicability of these theoretical explanations for education reform in Turkey is discussed.

European norms regarding education have emerged during the course of EU integration. Fostered mainly by the Council of Europe and its various projects on improving history education to promote democracy and human rights, the common European norms have been applied in the field of education in EU Member States (MS). As we will discuss in the next pages, they have become norms that Turkish civil society has been pressing for in the last decade. These non-governmental efforts are supported by financial instruments of the EU. Europeanization has therefore meant both a political and an economic trigger for domestic actors in Turkey on the road to substantive democracy.

\section{LINKING DEMOCRATIZATION AND EUROPEANIZATION AT THE THEORETICAL LEVEL}

One major independent variable in democratization studies has been international influence. The EU as an international actor influencing democratization has also emerged in this literature recently (Kubicek, 2003; Whitehead, 2001). Apart from the EU featuring as an independent variable in democratization studies, a distinct body of literature on Europeanization has developed in the last decade (Börzel, 1999; Cowles, Caporaso and Risse, 2001; Featherstone and Kazamias, 2001; Featherstone and Radaelli, 2003; Goetz and Hix, 2001). ${ }^{(1)}$ The two bodies of literature identified above do not necessarily speak to one another although democratization of the new Member States has become a significant component of Europeanization since the introduction of the Copenhagen Criteria in 1993. For the examination of the case of education in Turkey, Europeanization and democratization literature which focus on the EU as an external influence will be studied together.

The EU's role as an international influence was not given much attention in the 1980s. In a four volume study on democratic transition in the 1970s and 1980s, O'Donnell, Schmitter and Whitehead (1986) argued that democratization occurred mainly because of the "domestic forces and calculations" and that the international influences were not the major cause. In their volume on the democratic transition from authoritarian rule in Southern Europe, the external actors, the European Economic Community (EEC) being the main one at the time, had a "marginal" and rather "indirect" role by rewarding the transition process. (O'Donnell et. al., 1986: 4-5). On the other hand, Huntington (1991) viewed the same transition differently. The author argued that the EEC enlargement and US foreign policy in the 1970s had an important role in the Southern European transition. In relation to the fall of communism in Eastern Europe and the opening up of the regimes in these countries, Huntington points to the significance of the Helsinki process initiated by the EEC in 1975.

\section{Mechanisms of International Influences on Democratization, the EU as an International Influence}

Along with Huntington (1991), many studies in democratization started taking international influences seriously in the early 1990s. This was when the mechanisms with which international actors used to influence democratization started appearing in the literature. In their study which adopted a comparative outlook at the Southern European, Latin American and Central and Eastern European 
Countries' (CEECs) experiences in democratization, Stepan and Linz (1996) identified three major categories of international influence which have affected democratization. These categories were foreign policy of a hegemon, zeitgeist and the diffusion of democratic norms. While they identified the international influences as having a minor effect in Latin American countries and an indirect one in Southern Europe, the authors argued that the diminishing hegemonic role of the Soviet Union in the satellite countries and the increasing role of the EU had been the most important variables in determining the democratization of the CEECs.

More recently, Whitehead (2001) has argued that such an international impact has been possible through three mechanisms: contagion, control, and consent. While contagion explains democratization through geographical proximity, control refers to the direct control of domestic institutions by democratic foreign powers. Consent is the voluntary transition of domestic actors to a democratic regime with a certain backup of the international actors. In the same book, Schmitter (2001) argued that conditionality was emerging as the main mechanism of international impact on democratization. Although initially applied by international organizations such as the IMF, and NATO, according to the author, the EU conditionality has been the most effective use of that mechanism in democratization because of the permanent nature of EU membership with its economic and social benefits and complex interdependence. Schmitter (2001) adds that democratization is not the result of commerce or the interconnectedness of economies but rather the communication among the Member States and the candidate countries when the impact of the EU is concerned.

As we are in what Schmitter (2001) called the "fourth wave" of democratization which was not produced by an event unlike the previous waves of the international norm diffusion, contagion has become the main mechanism of democratization. By contagion, the author did not refer to geographical proximity but instead to communicative interdependence. He argued that each successive case created more linkages with the formal non-governmental organizations. In this respect, it is more important to have interconnectedness among non-governmental actors and intelligentsia now compared to the value of intergovernmental channels of influence in the past. The international context that supports democratization has therefore become more regional rather than global or binational.

Along the same line with Schmitter (2001), Kubicek (2003) argued that the EU was transformed from being a trading bloc to that of a political union aspiring to be a regional power both in economic and political terms. The foreign relations of the EU have altered in this respect with a greater emphasis on democratization, human rights, pluralism and the rule of law enshrined in the European Council declarations, treaties and cooperation agreements with post-Communist countries. All these changes were embodied in the Copenhagen Criteria which stressed democratic institutions, the rule of law, and respect for and protection of minorities and human rights in addition to the economic criteria. The author argued that the mechanisms through which the EU as an international actor influenced democratization were convergence and conditionality. What was meant by convergence was the internationalization of norms at the domestic level by the persuasion of the EU, based on constructivist arguments, while conditionality was rather a rational actor model of politics based on the carrot and stick mechanism.

More recently, the 'gravity model' which was originally an international trade model, has been applied to the democratization impact of the EU in its more immediate relationships. The gravity model assumed that international trade would grow close to a strong trading center. Emerson and Noutcheva 
(2005) argued that the same should apply to centers of democracy and their neighborhood; therefore the strong centers of democracy would foster the democratization of their neighborhood. Pointing to the two strong centers of democracy such as the United States and Europe, the former with a minor impact and the latter with a greater impact on democratization, the authors argued that the gravity model applied in the case of the EU due to political conditionality and socialization mechanisms of Europeanization, hence creating a strong correlation between Europeanization and democracy. With these mechanisms, the neighboring countries of the European Union became more democratic. The Europeanization process led some countries to become members of the European Union, while other countries, even though they did not become members, took important steps on the road to sustainable development and democracy. The authors further asserted that such a gravity force did not arise between the democratic North American and the mostly autocratic Latin American countries because of the lack of a catalyzing factor which would promote such democratization and diffusion of democratic norms.

As we have seen, democratization studies have accepted the influence of the EU as an international actor starting with the 1990s. While there is no academic consensus on the impact of the EU in the Southern European transition to democracy, there is no doubt about the role of the EU in the transition of the CEECs to democracy. The EU influence was studied within the general mechanisms of previous international influences. More recently, distinction has been made with the EU impact and other international actors. Convergence, conditionality and gravity models have been used to explain the distinct impact of the EU on democratization.

Another change concerns what democracy and democratization have meant. Previously most democratization literature was about regime change, that of transition from non-democratic to democratic regimes: Recently, there has been more literature on the states that have been democratic for a long time but have been reluctant to bring their democracy to higher standards; to that of a substantive democracy. ${ }^{(2)}$ This is where Europeanization literature might be complemental to democratization literature.

\section{Europeanization Theories and the Mechanisms of EU Impact}

As the democratization theory is gradually accepting the EU as an independent or an intervening variable, studies of Europeanization in the new MSs and candidate countries gain a new momentum. Previously studied as European integration or institutional reform at the member state level, the new vein in literature, Europeanization, is defined as the "emergence and development at the European level of distinct structures of governance, that is of political, legal and social institutions" which lead to the creation of authoritative European rules (Cowles et al., 2001).

The Europeanization model proposed by Cowles, Caporaso and Risse (2001) is cited in almost all studies on Europeanization. Building on a historical institutionalist perspective, the authors argued that in order for Europeanization to occur, there must be some misfit between the national and the European level policies. When such misfit exists, whether or not Europeanization occurs depends on the level of adaptational pressure at the national level. In order for Europeanization to facilitate domestic change, the mediating factors should overcome the pressure arising out of the need between adaptation and resistant actors. 
The authors argued that Europeanization not only affected formal structures but also the shaping of informal structures such as state identities and citizenship norms. In the same vein, Checkel (2001) and Risse (2001) pointed out the importance of norm diffusion as a mechanism of Europeanization. Checkel (2001) argued that the Council of Europe and EU treaties in the 1990s set important norms about the idea of European citizenship. These norms have been well diffused among the national actors in Germany which in turn have led to changing the legal status of German citizenship from an ethnic definition based on blood ties to a civic one based on being born in a given territory. Political actors at the national level were eager to bring citizenship norms to European standards. European norms were well diffused among and supported by other societal actors like the Church and civil society organizations. Europeanization occurred although domestic norms about German citizenship were historically well institutionalized because domestic actors were successful in overcoming the adaptational pressure.

This is where democratization and Europeanization literature are linked because both of them examine the so-called norm diffusion at the local level. Norm diffusion is important for the fact that it does not directly link to membership prospect; therefore one could talk of the diffusion of European norms in countries like Turkey and Ukraine where membership is not yet on the table, but, nevertheless, democratization proceeds.

In a later study Börzel and Risse (2003) differentiated between a rational institutionalist and a sociological institutionalist model to study the impact of Europeanization on domestic policy. While having similar assumptions about misfit and pressure, these two models differ in their conceptualization of mediating factors. Rational choice institutionalism suggests that with Europeanization, there is a new re-distribution of power at the domestic level and the actors who have the ability to exploit these opportunities facilitate the domestic change. On the other hand, the sociological (constructivist) model puts the emphasis on the process of persuasion, where "norm entrepreneurs" or "change agents" facilitate a socialization and collective learning process which leads to domestic change.

Schimmelfennig and Sedelmeier (2004) argued that the EU rule transfer at the local level is best explained by the external incentives model where the domestic status quo is altered by conditionality. The government is either targeted directly by intergovernmental bargaining or indirectly by empowerment of domestic actors. The authors argued that this model has been effective in the CEECs because of the credibility of EU conditionality. Therefore one could argue that the impact of the EU is better explained with conditionality when the membership prospect is on the table.

Sedelmeier (2006) argued that the EU's impact on the frontrunners of democracy in Central and Eastern Europe like the Czech Republic, Poland and Hungary in the adoption of liberal democratic norms was successful with the use of conditionality in issues like minority rights. However, in countries with a nationalistic and authoritarian leadership like Romania, Croatia and Slovakia the impact of the EU was minor. But once the liberal forces gained electoral support in these countries, the EU conditionality worked.

\section{THE IMPACT OF EUROPEANIZATION IN THE FURTHER DEMOCRATIZATION OF TURKEY}

Turkey has had a history of multi-party democracy since 1946. Although three military interventions in 1960, 1971 and 1980 distorted the functioning democracy, long term military dictatorships as in 
the example of Southern Europe in the 1970s were not the case in Turkey. The difference in the experience with democratization is even more different when compared with the CEECs which were transition countries in the 1990s. Therefore the impact of Europeanization on democratization has not been as vast in Turkey as it has been in the CEECs in the 1990s and 2000s. However, Europeanization has been part of Turkish democratization for a longer period of time. Some coin Europe as a historical anchor for Turkey while others study Europe as one of the international institutional factors leading to democratization. Nevertheless, there is no doubt that the EU has been an international actor that has affected domestic policy and institutions in Turkey to a great extent over the last decade because the EU accession has been one of the most important determinants of political reforms in Turkey.

Turkey falls within the gravity perimeter of the European Union, and recently democratization and Europeanization have come to identify the same process in the country. The two words are used almost interchangeably. In addition, government officials such as the Chief Negotiator Egemen Bağış (2010) put forward the argument that even if Turkey does not become a full member of the European Union in the near future, the reforms undertaken are important for the country because of the will to improve the Turkish democracy. Europeanization is presented as the right path of democratization with guaranteed success.

While the political will constantly reassures the public and the EU authorities about Turkey's determined membership bid, the public support has been declining. Apart from the decline of public support, there is consensus that the reform process which had accelerated since Turkey's candidacy, slowed down after 2005. Alpay (2008) argued that negative signals to Turkey coming from the EU's soft power has diminished Turkey's willingness to adopt European norms. Ulusoy (2009) claimed that uncertainty in Turkey - EU relations seriously affected the internal dynamism of the reform process and produced resistance to democratization.

Historically, "Europe" and "the West" have been identified as anchors beginning with the foundation of the Republic and have provided the ideals for the progress of the regime. Keyman (2007) argued that the central ideology during the foundation and early years until of the Republic had been modernization. While democratization determined the period between 1950 and 1980, globalization was the motto of 1980 to 2000 leaving Europeanization as the dominant ideology from 2000 onwards. The candidacy status of Turkey in 1999 has made Europeanization the dominant ideology embraced by many actors in the society.

Although this periodization is an accurate one, we have to distinguish between the understanding of democratization in the 1950s and that of today. Democratization in Turkey has been understood in terms of belonging to the Western alliance, the so called "free world" as a buffer zone between two ideological blocs. Today individual rights and freedoms form the major issue of democratization in Turkey. One of the main reasons is the EU conditionality itself. Until the 1999 Helsinki Summit, Turkish membership applications were rejected on the grounds that Turkey had a poor human rights and democracy record. A similar reasoning has been present in the progress reports. Hence, democratic conditionality has been applied with concerns that are not necessarily the democratization concerns of the political actors of a country. To give an example for Turkey, the democratization conditionality has not been related to the priorities of the political elite but rather to that of disadvantaged groups who were able to communicate their complaints to the EU decision makers (Alpay, 2004; Ulusoy, 2009). 
As mentioned above, the Europeanization process of Turkey is traceable back to the Tanzimat Period almost 200 years ago (Ulusoy, 2009). The early periods of Europeanization were coupled with the intention of the political elite to reform the state. Up until the last decade, Europeanization had never meant democratization. At the moment, the EU accession process and the Europeanization of Turkey pose pressures for Turkey to democratize by focusing on the problems of subnational groups. The claims of these groups have been voiced through and backed up by the progress reports of the EU. Consequently, today democratization constitutes the essence of Europeanization in Turkey.

The difference between Turkey and that of the Central and Eastern European Countries is that the democratic conditionality applied to those countries meant that the adoption of the fundamental political principles of the EU, the norms of human rights and liberal democracy, in the accession period was mainly top down. However, in Turkey the democratization process could be traced back to the political transformation in the post- 1980 period and has been, instead, bottom up. The way the democratization process has been equated with the Europeanization process is the fact that domestic actors that the author calls "subnational groups" are mobilized at the European level (Ulusoy, 2009).

If we test the Turkish case with the rationalist institutionalist model, we see that the benefits of the EU carrots are uncertain because of the open-ended negotiations and frozen chapters due to the Cyprus issue and the recently blocked chapters due to current French leadership's opposition to the membership of Turkey. Therefore, a strong empowerment of domestic actors that would induce democratic change has not been possible. To test the domestic impact of the EU with conditionality or the rational choice institutionalist version of Europeanization provides a perspective which fails to recognize the democratization momentum in Turkey. The sociological institutionalist perspective which takes into account the diffusion of norms, social learning and lesson drawing mechanisms leads us to grasp the domestic impact of the EU better because those mechanisms have been spread over a longer period of time and do not come to a direct impass with political crises. This paper offers to test this explanation by focusing on education as a domestic policy area in Turkey which has gone through reforms in the name of democratization and Europeanization.

\section{EUROPEANIZATION AND CHANGE IN EDUCATION NORMS}

Education together with culture is one of the negotiation chapters in the accession process of candidate countries to the European Union. Although, as previously stated, it is not a common policy area and the impact of political conditionality in this area is limited to instances when issues of human rights, women's rights and the rights of minorities are in question. These issues are raised in the annual progress reports of the commission and accession partnership documents with candidate countries. What is expected from the candidate country with the negotiations is the implementation of the acquis concerning education and the participation in community wide programs by establishing the necessary domestic institutions.

In addition, conditions are set for education in the progress reports prepared by the Commission when domestic policies are considered to be in conflict with human rights, identities of minorities and religious freedoms. In this regard, progress reports and accession partnership documents point to norms set by the European Court of Human Rights (EctHR) and the Council of Europe (CoE). Through these documents that determine the faith of the accession negotiations, the EctHR and CoE norms are reproduced. With this mechanism, EU institutions and accession documents use norms developed by non-EU European institutions in Strasbourg to foster integration. 
Apart from accession documents, the political integration of the EU has facilitated common norms about education through treaty articles on citizenship, human rights and minorities. Greater emphasis was placed on the role of education with the Treaty of Lisbon when the EU set its goal of becoming a knowledge-based economy. The Treaty called for the improvement of education in order to meet the challenges of the global economy. As a response, the Union undertook the duty of contributing to the "quality of education by encouraging cooperation between member states" (Treaty of Lisbon, Article 165 (1)). Subsequent articles of the Treaty call for a European dimension in education through the "teaching and dissemination of languages of member states" (Article 165 (2)).

In addition, the Bologna process, started as an EU initiative and developed into a mission with a greater scope that reached up to 47 members, is another European project that has fostered integration and standardization of education within and in the immediate neighborhood of the EU. The process aims at standardizing university course credits, diplomas and degrees within the European Higher Education Area (EHEA) while increasing the competitiveness of higher education in Europe (Bologna Declaration, 1999).

The content of secondary school education has been shaped during the course of the European integration as well. Although EU treaties do not refer directly to educational material and the content of education, this has been an important working area for the Council of Europe since its foundation in 1949. "Mutual understanding and confidence amongst the peoples of Europe" (CoE) has been one of the priorities of the Council, and it has worked "to incorporate the principles of human rights, democracy, tolerance and mutual respect, the rule of law and peaceful resolution of conflicts into the daily practice of teaching and learning." Council activities are organized under cooperative programs, annual conferences and projects. The national ministries and other international organizations such as UNESCO are working partners with the Council of Europe in the area of education.

In line with the institutional norm setting at the EU level, history classes at school have been regarded as a starting point to overcome political conflicts and to foster mutual understanding between the peoples of Europe. Three different joint history projects have come to life in Europe, all intending to foster an idea of a common understanding of the past in order to overcome the biased, stereotyped national historiography. The first one of these projects was the German-French textbook project which was published and distributed in 2006 as a textbook written by a group of French and German historians. A similar cooperation of history and geography textbooks has existed between Germany and Poland since the mid-1990s. Another joint project about history textbooks is the joint teachers' manual for the Balkan history published by the CDRSEE (Center for Democracy and Reconciliation in Southeast Europe) in 2005. These volumes aim at counterbalancing nationalist ideologies and historiographies, avoiding a reproduction of stereotypes and promoting the idea of multiple interpretations of the past. All these projects were funded and supported by European institutions which aim at such a common understanding of the history of Europe, freed from stereotypes.

In light of the discussion above, we could argue that European educational norms have been developed over the years with respect to human rights, the protection of minority cultures and identities and a shared history of European people which could make a basis for a common European identity. 


\section{ADOPTION OF EUROPEAN NORMS IN TURKISH EDUCATION}

When the youth of Turkey are considered, education stands out as a key policy area. There are around 15 million students at the primary and secondary education institutions in Turkey (TCMEB 2006: 21) and half of Turkey's 73 million population is under the age of 29 (TÜİK, 2010). Around $75 \%$ of these students are enrolled in public schools. The budget allocated to education totals about $€ 14$ billion. Public as well as private schools have to follow the curricula approved by the Ministry of Education and are subject to the same regulations as those of the public schools. The Ministry of Education is the central governing mechanism administering national education with duties ranging from the preparation of the curricula to the construction of schools.

\section{The Government's Reform Agenda and Response to the EU Accession Process}

Education is a policy area where the impact of the EU in Turkey can be observed at different levels. At the governmental level, the requirements rising out of the negotiation chapter on dealing with education and culture have been met to a great extent as the country takes part in almost all community wide programs such as Erasmus, Socrates, Life Long Learning and Youth in Action. A national agency was established in 2002 to carry on the administration of these programs. Since then its capacity has been increased to enable it to deal with the increasing workload as the country takes part in a greater range of projects.

At the governmental level, there is growing concern over education because of the large number of young people in Turkey and the poor record of the country in the 2003 and 2006 PISA studies. ${ }^{(3)}$ The government's reform plan is mainly about increasing and modernizing the capacity and educating its youth for the needs of the global economy and the job market. The major reform project in 2004 carried out by the Ministry of Education aimed at achieving these aims. This reform package included a change of curriculum as well, but it, too, was designed to meet the above stated aims of modernizing the material. As many authors argue, the curriculum reform was merely an injection of the neo-liberal discourse in education (Akkaymak, 2008; İnal, 2008). As a member of the history curriculum committee noted, improving the entrepreneurial capacity of the students was given utmost importance. ${ }^{(4)}$

With the candidacy process, the Ministry of Education set up a commission responsible for the harmonization of the Turkish national education with the acquis communautaire. In a publication prepared by this commission, the education systems of Turkey and the MSs were analyzed in a comparative perspective (TCMEB 2006). The comments in this report by the Minister of Education Hüseyin Çelik, and the ministry's general manager for foreign affairs are important in this respect. Çelik stated that education was a national policy area and that the national education in Turkey was generally compatible with that of the MSs. However, there were EU expectations which were presented in the annual progress reports with the note that the ministry had started to work to meet these expectations. Under the major six headings of reform identified by the Ministry, the first one was the improvement of primary and secondary school curricula. The other five headings were related to the improvement of physical and technological capacity, percentage of school attendance, teachers' capacity and counseling facilities. The primary and secondary school curricula had been adjusted "to educate qualified, specialized good citizens, good people with the priority of meeting the demands of the global economy and job market" (TCMEB, 2006: 8). The adjusted programs have been in effect since 2005-2006. 
In another statement, the reforms made with EU membership in mind were presented in line with a strategy to meet the challenges posed by the global economy. The "human capital" was seen as the key to competition in a global economy and the "criteria for being an honored and respected member of the European Union" (TCMEB 2006: 12). In this reform process, Turkey "benefits from both its own historical experiences and the experiences of the European Union in the policy area of education." As is apparent in these statements, both officials supported the idea that education has to be reformed for enhancing competition in the global economy and therefore adapting to the EU norms. There is not much reference to the problems in education to which the progress reports have drawn attention such as cultural rights which are related to the democratization process. These issues, which will be underlined below, have traditionally been viewed as a national matter and as "our characteristics and distinctions" (Aktar, 2001: 11), and reform in these issues has been slow although there is societal pressure.

\section{Societal Actors and their Stake in the EU Accession Process}

At the societal level, the subnational groups and the civil society organizations have identified civil rights calling for a liberalization of the education policy. The reform agenda pushed by the societal actors ranges from the right to education in one's native language to the right to be exempt from mandatory religious education and to the abolition of the authoritarian and monist content of education.

One of the main issues is the right to education in one's own religious belief proclaimed by the Alevis in Turkey. The religion class is mandatory for all Muslims from the $4^{\text {th }}$ to the $12^{\text {th }}$ grade. The content of the religion class, as in any other class, is determined by the Ministry of Education. The content of the religion class is determined in accordance with the Sunni, specifically the Hanefi, interpretation of Islam. From the state's perspective, Alevis are Muslims who practice a heterodox version of Islam and hence there is no problem for children of these families taking this class. Alevi families argue that this is against their freedom to learn their own religion and therefore they do not want to comply with the mandatory curriculum. In 2001, an Alevi parent's demand to withdraw his child from the religion class was rejected by the representation of the Ministry of Education at the local level. This led the parent to take the matter to the local courts which decided that the class was mandatory. The case was then taken to the European Court of Human Rights in 2004. It ruled in 2007 that the religion class with its current content violated human rights. As a result, the classes were subject to a revision of the curriculum in 2006-2007, and a brief section on Alevism (Alevilik-Bektaşilik) was inserted in the curriculum. However, the revisions merely placed Alevism among the sufist interpretations of Islam. ${ }^{(5)}$ Alevi families still want their children to be exempt from the religion class.

Religion and education have recently been the concern of the European Commission as presented in the last Accession Partnership. In 2006, the Council decision took note of education in relation to several issues. The short term priorities involved women's rights and promoting the role of women in society through education and participation in the labor market. Medium term priority was assigned to the improvement of the economy with the education of the younger generation and the necessity for Turkey to align itself with EU policies for the protection of cultural diversity (European Council, 2006). The 2008 Council decision on the other hand, handled the issue of religious education for non-Muslim minorities and the training of clergy as a short term priority by pointing to the ECHR (European Convention on Human Rights) and the rulings of the EctHR. This clause specifically identified the demands by the Greek Orthodox community for training its clergy which had been made 
impossible with the closure of the Halki theological school in 1971. Women's education and education of the younger generation were repeated issues. (European Council, 2008).

The right to education in one's native language has become a major component of the cultural and political rights demanded by the Kurdish population. Proclaimed by the parliamentary representatives of the Kurdish voters and intellectuals and supported by various EU declarations, the right to education in one's native language was the major rights-based claim by the largest linguistic minority in Turkey in the democratization and Europeanization process. The right to learn the Kurdish language through private educational institutions which was introduced by the EU reform packages and the lifting of technical and psychological barriers in the public use of Kurdish language was found insufficient by many liberal civil society organizations and think tanks. Lately, TESEV's recommendation report on a democratic constitution to solve the Kurdish question stressed that pre-school age children whose mother tongue was other than Turkish should receive state-sponsored pre-school education in Turkish as a foreign language in order to learn the Turkish language prior to schooling. (Kurban and Ensaroğlu, 2008). The report further argued that the aim of the Law on National Education should be changed and the ideological and monist understanding of education should be replaced by a pedagogical understanding.

History classes and the content of the history textbooks are another area where the Europeanization process has proved to be a lever to use to change the existing monist and ideological discourse of education. Since the 1990s, textbooks and especially history textbooks have been under close scrutiny by civil society organizations, especially the History Foundation, teachers' groups, historians and academics from various university social science disciplines. These efforts were backed up by the pressures from TÜSİAD, the leading industrialists' organization in Turkey. This grouping is an exemplary instance in which the rights activists of the 1990s have all been present. They have called for a more democratic Turkey which they think is possible through the protection of the minority and the cultural and religious rights and the liberalization of the nationalistic discourse. Since the significance of history and other social sciences textbooks is still high in nurturing a population, a change in their content is strongly advised by these groups. Their cause has largely been supported by international actors such as various European institutions and UNESCO.

The History Foundation in Turkey has been actively drawing attention to the need for a substantial change in the curriculum and textbooks. The presentations of the international conferences and symposia they have convened have been published by the foundation in various volumes (Tarih Eğitimi, 1998; Özbaran, 1995, 2008; Balkan History Textbooks, 2001 etc.). The History Foundation's latest project about education has not been limited solely to the investigation of history textbooks and their low standards in history teaching but has included one under the general title of "Human Rights in School Textbooks" (2003 and 2009). The rhetoric of the EU norms and the Copenhagen criteria for membership in this title are immediately recognizable. The History Foundation, in its project funded by the European Union and the embassy of Finland in Turkey, is a clear-cut case of how the EU norms have become part of civil society claims on education.

In conducting a content analysis of primary and secondary school textbooks in Turkey with guidelines provided by international organizations such as UNESCO, the Council of Europe, the Georg-Eckert Institute for International Textbook Research, the researchers note that $92 \%$ of the textbooks suffer 
from abuses of Human Rights principles (Tüzün, 2009). The study also draws attention to the neglect by the state authorities in the previous studies of education material by the History Foundation and other civil society organizations. In a report on Turkey put out by the European Commission Against Racism and Intolerance (ECRI) in 2005, the authors argued that school textbooks have to be monitored by state authorities in close cooperation with civil society initiatives, and thereby point out another norm of EU governance that should be applied.

History classes provide an opportunity to foster the recognition of ethnic and religious pluralism, and are a step away from the monist discourse of Turkish nationalism that not only has dominated the history and social sciences but also education at large. When such a change in the curriculum occurs, then the other components of the education reform would become more meaningful and effective in completing Turkey's democratization efforts. ${ }^{(6)}$ As mentioned above, minority rights and cultural and political freedoms have met hesitation from government officials. More reforms are carried out in technical modernization but the claims based on human rights are generally left out.

\section{CONCLUSION}

Looking at the education reform in Turkey, two key issues of Europeanization have been identified in this paper. One of them is the Europeanization understood in terms of reaching European standards at a technical level and fulfilling standards identified by the accession documents. The other key issue is the democratization prospect that Europeanization offers for the adoption of norms developed at the European level. The statements of the Ministry of Education officials and the reforms that have already been carried out reveal that the technical Europeanization, the one triggered by EU institutions in Brussels, is the primary goal of the political elite in Turkey who try to reform education to meet the needs of the global economy both at the national and at the EU level. As far as taking part in community-wide education programs and the Bologna process, the education policy in Turkey has evolved parallel to the European Union in this respect. It could be argued that Turkey's education policy has been Europeanized to a large extent with the misfits between the two levels of policy being brought to a minimum.

On the other hand, when education policy and European norms on human, cultural and democratic rights are concerned, the reforms remain belated although the possibilities of reform in these issues are well identified by intellectuals, civil society organizations and what has been called the subnational groups. What these societal actors call for is the democratization of education beginning with the content. When the content of the classes in history calls for change, then the cultural uniqueness of Turkey is emphasized by the political elite. Therefore, we could argue that the second issue of internalizing the European norms of democracy, human rights and the protection of minorities, in other words the Strasbourg-centered Europeanization, has remained stagnant both because of the uncertainty of the EU conditionality and the nonperception of the need for reform in these issues. Although there is norm diffusion at the intellectual and pro-EU NGO level, these actors are not strong enough to persuade the political or state elite.

This paper has argued that the Europeanization and democratization processes that Turkey has gone through should be studied not only through a rationalist model of conditionality, meeting political and economic criteria and being accepted as an EU member. This mechanism alone fails to understand the

Europeanization process since membership is not on the table and the incentives for fulfilling the criteria 
are poor. A constructivist model where norm diffusion is the key mechanism of Europeanization, which seeks the answers over a longer period of time, is complementary to the first model and at times more useful in explaining the domestic impact of international influences.

Moreover, this article has argued that the Europeanization mechanisms could lead to a further democratization of the education policy in Turkey given the dynamism of intellectuals, civil society and subnational groups. This potential has been hampered by the uncertainty of the membership prospect. Further research should aim at two questions: a) whether EU norms will still have an impact in the future in domestic policy given the dynamic civil society and the old practices and mentalities, or b) whether this potential which exists today will vanish with a further slowing down of accession negotiations.

\section{NOTES}

1. One should note here that the Europeanization literature does not focus on Europeanization as a long term-process, which in countries like Turkey could be traced back to the $19^{\text {th }}$ century. As Diez, Agnantopoulos and Kaliber (2005) rightly put it, what Europeanization deals with should actually be termed as EU-ization because Europeanization means another process which is much older than the EU. Nevertheless, the term "Europeanization" is employed throughout the paper to avoid complications and to link with the previous literature on Europeanization.

2. The author is grateful for a comment on an earlier version of this article made by Frank Schimmelfennig about the EU impact on substantive democracy.

3. The PISA (Programme for International Student Assessment) is carried out by the OECD every three years in industrialized countires on 15-year-olds to assess students' effectiveness in reasoning, analyzing and reflecting on what they learn at school and to measure their knowledge and skills.

4. This finding is part of a larger dissertation project, and therefore the author is not allowed to disclose names of the interviewees.

5. See for example the most recent textbook for the religion class: Akgül et al. (2009) Ortä̈gr retim Din Kültürü ve Ahlak Bilgisi Ders Kitabı 12. Sintf. At the heart of the problem is the recognition at the state level that Alevis are Muslims and hence religious services and education for the Alevi population already exist. On the side of the Alevis, the recognition as a Muslim sect is rejected because the community demands a separate status and hence separate religious services and education.

6. At the beginning of the academic year 2011-2012, the government amended the law on education. In amendments made in 1982 and which were kept during the 1990s, the aim of education in this law was stated as raising the "future generations committed to Atatürk's reforms, Turkish nationalism, having internalized the national, moral, humanistic, spiritual and cultural characterisrics of the Turkish nation." The new Law on Education has omitted this sentence from the aims of education. While the new aims do not refer to democratic education with respect to human rights, the principles of a liberal economy and educating generations for the "needs of the 
market" are among the founding principles of the new law. Although the new law on education demands further analysis, the immediate results point to the same discrepancy in Europeanization that is identified in this article.

\section{REFERENCES}

2008 Y1lı Ulusal Programı. (2008). (National Program 2008). Available [online] at: http://www.abgs. gov.tr/index.php?p=42260\&l=1. [Accessed June 12, 2010]

Akgül, M. et al. (2009). Ortä̈ğretim Din Kültürü ve Ahlak Bilgisi. Ders Kitabı 12. Sinıf. (Textbook of Religion and Morality for Secondary Schools, Grade 12). Ankara: Devlet Kitapları Döner Sermaye İşletmesi Müdürlüğü.

Akkaymak, G. (2010). "Neo-Liberalism and Education: Analysis of Representation of Neo-Liberal Ideology in the Primary School Social Studies Curriculum in Turkey," Unpublished MA Thesis. İstanbul: Koç University.

Aktar, C. (2001). Avrupa Yol Ayrımında Türkiye (Turkey in the Crossroads of Europe). İstanbul: İletişim.

Alpay, Ş. (2005). "Crisis in the Identity Politics of Turkey," in I. Ahmed (ed.), The Politics of Group Rights. The State and Multiculturalism: 121-128. Maryland: University Press of America.

-----, (2008). “Making Sense of Turkish Politics,” The International Spectator, 43(3): 5-12.

Antoniou, V.L and Nuhoğlu-Soysal, Y. (2005). "Nation and the Other in Greek and Turkish History Textbooks," in H. Schisller and Y. Nuhoğlu-Soysal (eds.), The Nation Europe and the World. Textbooks and Curricula in Transition: 105-121. New York: Oxford: Berghahn Books.

Arıkan, Z. (2008). "Ders Kitaplarında Avrupa Tarihi (European History in Textbooks)," in S. Özbaran (ed.), Tarih Öğretimi ve Ders Kitapları (History Teaching and Textbooks): 145-160. İstanbul: Tarih Vakfı Yurt Yayınları.

Bağış, E. (2010). Hükümet ve Bürokrasinin Yeni AB Iradesi ve AB Ülkelerinin Türkiye'nin Üyelik Perspektifine Bakışlarl (The New EU Will of the Government and the Bureaucracy and the EU Member State Perspectives on Turkish Membership). Speech delivered on January 7, Istanbul: Bahçeşehir University.

Bologna Declaration. (1999). Available [online] at:

http://www.ond.vlaanderen.be/hogeronderwijs/bologna/documents/MDC/BOLOGNA_ DECLARATION1.pdf

Bora, T. (2003). "Ders Kitaplarında Milliyetçilik (Nationalism in Textbooks)," in B. Çotuksöken, A. Erzan, and O. Silier (eds.), Ders Kitaplarında İnsan Hakları: Tarama Sonuçları (Human Rights in Textbooks: Screening Results): 65-89. İstanbul: Tarih Vakfı Yayınları. 
Börzel, T.A. (1999). "Towards Convergence in Europe? Institutional Adaptation to Europeanization in Germany and Spain,” Journal of Common Market Studies 39(4): 573-96.

Börzel, T. and Risse, T. (2003). "Conceptualizing the Domestic Impact of Europe," in K. Featherstone, C.M. Radaelli (eds.), The Politics of Europeanization: 57-79. New York: Oxford University Press.

Checkel, J. (2001). "The Europeanization of Citizenship," in M.G. Cowles, J. Caporaso, and T. Risse (eds.) Transforming Europe. Europeanization and Domestic Change: 180-197. Ithaca: Cornell University Press.

Copeaux, E. (1998). Türk Tarih Tezinden Türk İslam Sentezine Tarih Kitaplarında 1931-1993 (From Turkish History Thesis to Turkish Islamic Synthesis in Textbooks 1931 -1993). İstanbul: Tarih Vakfı Yurt Yayınları.

Council of Europe. (CoE) History Teaching in Perspective - Introduction. Available [online] at: http://www.coe.int/t/dg4/education/historyteaching/perspective/perspectiveintro_EN.asp [Accessed June 12, 2010]

Cowles, M.G., Caporaso, J., and Risse, T. (eds.) (2001). Transforming Europe. Europeanization and Domestic Change. Ithaca: Cornell University Press.

Çotuksöken, B., Erzan, A., and Silier, O. (eds.) (2003) Ders Kitaplarında İnsan Hakları: Tarama Sonuçları (Human Rights in Textbooks: Screening Results). İstanbul: Tarih Vakfı Yayınları.

Dierkes, J. (2005). “The Decline and Rise of the Nation in German History Education," in H. Schissler and Y. Nuhoğlu-Soysal (eds.), The Nation Europe and the World. Textbooks and Curricula in Transition: 82-102. New York: Berghahn Books.

Diez, T., Agnantopoulos, A., and Kaliber, A. (2005). "Introduction," Journal of South European Society and Politics, 10(1): 1-15.

Eğitim Reformu Girişimi. (2009). Eğitim İzleme Raporu 2008 (Education Monitoring Report 2008). İstanbul: Sabancı Üniversitesi.

Emerson, M. and Noutcheva, G. (2005). "Europeanization as a Gravity Model of Democratization," Herald of Europe, 2: 1-33.

European Council. (2006). Accession Partnership Agreement with Turkey 2006/35/EC.

------, (2008). Accession Partnership Agreement with Turkey 2008/157/EC.

Eurydice, (2010). National Summary Sheets on Education Systems in Europe and Ongoing Reforms, Turkey 2010. European Commission. Available [online] at: http://eacea.ec.europa.eu/ education/eurydice/documents/eurybase/national_summary_sheets/047_TR_EN.pdf [Accessed June $12,2010]$. 
Featherstone, K. and Kazamias, G. (eds.) (2001). Europeanization and the Southern Periphery. London: Frank Cass.

Goetz, K.H. and Hix, S. (eds.) (2001). Europeanized Politics. European Integration and National Political Systems. London: Frank Cass.

History Foundation (2001). Improvement of Balkan History Textbooks Project Reports. Istanbul: History Foundation.

Huntington, S.P. (1991). The Third Wave: Democratization in the Late Twentieth Century. Norman: University of Oklahoma Press.

İnal, K. (2008) Eğitim ve İdeoloji (Education and Ideology). İstanbul: Kalkedon Yayınları.

Kadıoğlu, A. (1996). "The Paradox of Turkish Nationalism and the Construction of Official Identity," Middle Eastern Studies 32(2): 177-193.

Kanc1, T. (2008). Imagining the Turkish Men and Women: Nationalism, Modernism and Militarism in Primary School Textbooks, 1928 - 2000. Unpublished Ph.D. thesis. Istanbul: Sabanci University.

Kaplan, İ. (1999). Türkiye’de Milli Ĕ̆itim İdeolojisi ve Siyasal Toplumsallaşma Üzerindeki Etkisi (Ideology of National Education in Turkey and its Impact on Political Socialization). İstanbul: İletişim.

Keyman, F.E. (2007). Remaking Turkey: Globalization, Alternative Modernities, Democratization. Oxford: Lexington.

Koulouri, C. (ed.) (2002). Clio in the Balkans, the Politics of History Education. Thessaloniki: CDRSEE.

Kubicek, P.J. (2003). The European Union and Democratization. New York: Routledge.

-----, (2005). “The European Union and Democratization 'From Below' in Turkey." Paper presented at the Biannual Conference of the European Union Studies Association, Austin, Texas, (March April).

Kurban, D. and Ensaroğlu, Y. (2008). Kürt Sorunun Çözümüne Dair Bir Yol Haritası: Bölgeden Hükümete Öneriler (A Roadmap for the Solution of the Kurdish Problem: Recommendations from the Region to the Government). İstanbul: TESEV Yayınları.

O’Donnell, G., Schmitter, P.C., and Whitehead, L. (eds.) (1986). Transitions from Authoritarian Rule. Southern Europe. Baltimore: Johns Hopkins University Press.

Nuhoğlu-Soysal, Y., Bertilotti, T., and Mannitz, S. (2005). "Projections of Identity in French and German History and Civics Textbooks," in H. Schissler and Y. Nuhoğlu-Soysal (eds.), The Nation Europe and the World. Textbooks and Curricula in Transition: 13-34. New York: Berghahn Books. 
Nuhoğlu-Soysal, Y. and Schissler, H. (2005). "Introduction. Teaching Beyond the National Narrative," in H. Schissler and Y. Nuhoğlu-Soysal (eds.), The Nation Europe and the World. Textbooks and Curricula in Transition: 1-9. New York: Berghahn Books.

Özbaran, S. (ed.) (2008). Tarih Öğretimi ve Ders Kitapları (History Teaching and Textbooks). $2^{\text {nd }}$ ed. İstanbul: Tarih Vakfı Yurt Yayınları.

Risse, T. (2001). "A European Identity? Europeanization and the Evolution of Nation-State Identities," in M.G. Cowles, J. Caporaso, and T. Risse (eds.) Transforming Europe. Europeanization and Domestic Change: 198-216. Ithaca: Cornell University Press.

Sakaoğlu, N. (2003). Osmanlı'dan Günümüze Eğitim Tarihi (The History of Education from the Ottomans until Today). İstanbul: Bilgi Üniversitesi Yayınları.

Schmitter, P.C. (2001). "The Influence of the International Context upon the Choice of National Institutions and Policies in Neo-Democracies," in L. Whitehead (ed.), The International Dimensions of Democratization. Europe and the Americas. Expanded Edition: 26-54. New York: Oxford University Press.

Schimmelfennig, F. and Sedelmeier, U. (2004). "Governance by Conditionality: EU Rule Transfer to the Candidate Countries of Central and Eastern Europe," Journal of European Public Policy, 11(4): 661-679.

Schimmelfennig, F. (2005). "Strategic Calculation and International Socialization: Membership Incentives, Party Constellations and Sustained Compliance in Central and Eastern Europe," International Organization, 59(4): 827-860.

Schissler, H. and Nuhoğlu-Soysal, Y. (eds.) (2005). The Nation Europe and the World. Textbooks and Curricula in Transition. New York: Berghahn Books.

Stepan, A. and Linz, J. (1996). Problems of Democratic Transition and Consolidation. Southern Europe, South America and Post-Communist Europe. Baltimore: Johns Hopkins University Press.

Sedelmeier, U. (2006). Europeanisation in New Member and Candidate States. Available [online] at: http://www.livingreviews.org/lreg-2006-3 [Accessed on June 14th 2010]

T.C. Milli Eğitim Bakanlığı. Dış İlişkiler Genel Müdürlüğü, (2006). Türkiye ve Avrupa Birliği Ülkelerinin Eğitim Sistemleri (Education Systems of Turkey and EU Member States), Ankara: T.C. Milli Eğitim Bakanlığı.

Tarih Vakfı, (2007). "Tarih Eğitimi ve Tarihte ‘Öteki’ Sorunu” (History Education and the Problem of the "Other" in History). 2. Uluslararası Tarih Kongresi, 8-10 Haziran 1995, 2nd ed. İstanbul: Tarih Vakfı Yurt Yayınları. 
TÜİK (Türkiye İstatistik Kurumu). 2010. “Adrese Dayalı Nüfus Kayıt Sistemi 2010 Y11 Sonuçları (Results of the Population Registry System based on Home Address 2010)," Nüfus ve Vatandaşlik İşleri Genel Müdürlüğü Haber Bülteni (Bulletin of the Directorate General for Population and Citizens), (19). Available [on line] at: http://tuik.gov.tr/PreHaberBultenleri.do?id=8428

Tüzün, G. (ed.) (2009). Ders Kitaplarında İnsan Hakları II. Tarama Sonuçları (Human Rights in Textbooks: Screening Results). İstanbul: Tarih Vakfı.

Ulusoy, K. (2009). "The Changing Challenge of Europeanization to Politics and Governance in Turkey," International Political Science Review, 30(4): 363-384.

Vachudova, M.A. (2005). Europe Undivided: Democracy, Leverage and Integration after Communism. Oxford: Oxford University Press.

Whitehead, L. (ed.) (2001). The International Dimensions of Democratization. Europe and the Americas. Expanded Edition. New York: Oxford University Press.

Youngs, R. (2009). "Democracy Promotion as External Governance?" Journal of European Public Policy, 16(6): 895-915. 